\title{
ENGEVISTA
}

Página da revista: http://www.uff.br/engevista/seer/

\section{Biomass gasification for power generation: a comparison with steam boilers in the brazilian scenario}

\author{
João Miguel ${ }^{1}$ \\ Tiberio Filho ${ }^{2}$ \\ Ricardo Pereira ${ }^{3}$ \\ Aymer Maturana $^{4}$
}

\begin{abstract}
This work compares biomass gasification and conventional direct combustion in steam boilers for producing power in the context of Brazilian sugar cane mills. The objective of this technical report is to show that gasification could be a more attractive way to convert biomass in energy, compared to using steam boilers, which in some cases can show a low efficiency. The idea is to use the gasifiers in sugarcane mills that have low pressure boilers $\left(21\right.$ to $\left.42 \mathrm{kgf} / \mathrm{cm}^{2}\right)$ that are currently dedicated only to generate steam or electrical power for the mill own energy consumption. The results shows that gasification could be a costeffective alternative for power production in Brazilian sugar cane plants with some additional advantages like the bagasse usage between the season and off-season periods to maintain a constant power generation throughout the entire year, higher energy availability and efficiency. However, nowadays in Brazil the economic advantage of gasification depends highly on political support and reliable long-term stable political framework conditions with an enough timeframe for the development, construction and operation of biomass gasification plants.
\end{abstract}

Keywords: Biofuels, fuels production, combustion, bioenergy, bagasse.

\footnotetext{
${ }^{1}$ Brazil Technology Center GE Global Research

${ }^{2}$ Brazil Technology Center GE Global Research

${ }^{3}$ Brazil Technology Center GE Global Research

${ }^{4}$ Brazil Technology Center GE Global Research
} 


\section{Introduction}

The share of sugarcane products in the Brazilian energy flow in 2013 accounted for about $16.1 \%$ of the total (or $47.6 * 10^{6}$ toe (tons of oil equivalent)). Looking only at the part of electricity generation toward the commercialization, the biomass (including wood, sugarcane bagasse and black liquor) was responsible for $7.6 \%$ of the total generation (46.4 TWh). The technology currently used in sugarcane mills is a boiler followed by a steam turbine.

The Brazilian energy sector has been subject to major changes. Particularly, since the implementation of the National Alcohol Program (Proalcool) in 1975 and recently has led important changes that has turned into a global trend, characterized by the growing increase of the contribution of biomass in the energy (biomass today represents $41 \%$ of renewables in Brazilian energy matrix) thanks to its use as a source for generating electricity.

In this context, the sugar and ethanol industry is undoubtedly a relevant actor because, through conventional systems (furnaces burn biomass, boilers generate steam using the heat produced in combustion and steam turbines generates electricity) cogeneration energy comes important producing and selling surplus electricity to the national interconnected system. A few years ago, biomass used to generate energy was only wood and bagasse and straw were considered as a problematic waste without any economic importance.

However, after the discovery and awareness about the energy potential of these materials, bagasse has become the most important source of biomass for power generation in sugar and ethanol industry, starting to have now a significant commercial value (US\$ 25 to US\$ 35 per ton out of the plants).

One of the technologies for producing energy from biomass which are being evaluated is gasification. Gasification is a thermochemical process that converts a hydrocarbon or mixture (homogeneous or not) of these materials into a combustible gas that can be used directly to generate electricity or produce different high value chemicals such as plastics, fertilizers, liquid or gaseous fuels, achieving extract between $75 \%$ and $80 \%$ of the energy content of the feedstock (CIFERNO, J. P. \& MARANO, J. J. 2002). The gasification presence in Brazil dates back to the period of the Second World War, when the scarcity of petroleum fuels allowed the use of "gasogênio", as were commonly called the Gasifiers adapted to move vehicles, as one solution implemented in some places of the world to prevent the collapse of public transport systems (CENBIO 2002).

According to (Boerrigter and Rauch, 2006), the principal raw material used to produce energy and chemicals from syngas has been coal and natural gas. In the case of biomass, the use to generate electricity and liquid fuels is becoming increasingly important and growing global market for gasification. In the context of the sugar industry, gasification of biomass could be understood as forming an integrated thermoelectric energy generation with a simple or 
combined cycle, where the combustible gas formed is passed into a gas turbine or a reciprocating engine or air derivative gas turbine coupled to an electric generator.

The installed capacity of electricity generation from biomass in Brazil reached 7.8 GW by the end of 2010, generating a total of 28 TWh (REN21, 2011). Most of this capacity is represented by cogeneration plants in sugar mills using bagasse and in some cases, straw as feedstock.

\section{Nomenclature}

$\begin{array}{ll}\text { Capex } & \text { Capital Expenditure } \\ \mathrm{CT} & \text { Cane tons } \\ \mathrm{IGCC} & \text { Integrated Gasification Combined Cycle } \\ \mathrm{IRR} & \text { Internal Rate of Return } \\ \mathrm{GW} & \text { gigawatts } \\ \mathrm{kg} & \text { kilogram } \\ \mathrm{kgf} / \mathrm{cm}^{2} & \text { kilogram-force per square centimeter } \\ \mathrm{kg}_{\mathrm{H} 2 \mathrm{O}} & \text { kilogram of water } \\ \mathrm{kg}_{\text {Bag }} & \text { kilogram of bagasse } \\ \mathrm{kg}_{\mathrm{Cane}} & \text { kilogram of cane } \\ \mathrm{kg}_{\mathrm{Gas}} & \text { kilogram of gas } \\ \mathrm{kJ} & \text { kilo Joule } \\ \mathrm{K} & \text { Kelvin } \\ \mathrm{LHV} & \text { Low Heat Value } \\ \mathrm{MW} & \text { megawatt electric } \\ \mathrm{MWh} & \text { megawatthour } \\ \mathrm{MJ} & \text { Mega Joule } \\ \mathrm{MW} & \text { megawatthour electric } \\ \mathrm{MW} & \text { megawatt thermal } \\ \mathrm{MM} & \text { millions } \\ \text { toe } & \text { tons of oil equivalent } \\ \text { ton/h } & \text { tons per hour } \\ \mathrm{TWh} & \text { terawatt hour } \\ \mathrm{t}_{\mathrm{Bag}} & \text { tons of bagasse } \\ \mathrm{t}_{\mathrm{Cane}} & \text { tons of cane } \\ \mathrm{T}_{\text {vap }} & \text { temperature of vaporization } \\ \mathrm{Yr} & \text { year } \\ & \end{array}$

\section{Methodology}

For the present analysis, was considered a typical Brazilian sugarcane mill (2 MM tons of crushing cane per season) with a low pressure boiler $\left(21 \mathrm{kgf} / \mathrm{cm}^{2}\right)$ only to produce steam for its internal consumption at a rate of $400 \mathrm{~kg}$ of steam per ton of processed cane. It's important to 
emphasize that energy or steam demands changes when the sugar and ethanol production ratio varies and this shift is very dependent on market conditions (price of these both commodities in the global market). The energy demand also varies according to the mill's automation level, where a high level of automation means a smaller consumption of steam.

An economical and technical comparison were done considering that during season operation (assumed 180 days) is necessary to supply steam and energy to mill operation, being the surplus bagasse used to produce energy and exporting it to grid. During off-season operation, all bagasse available should be used to produce energy and exporting it to grid, bringing more revenues to the business, since the normal sugar/ethanol production process is turned off and the mill goes into maintenance during this period.

The total quantity of bagasse available, considering only the amount coming from the grinding of $2 \mathrm{MM}$ tons of sugarcane (280 thousands of tons) was re-arranged in such a way that in the season and off-season operation, the same amount of power would be exported to the grid. Older mills typically have a higher demand for process steam, around $550 \mathrm{~kg}$ per ton of processed cane. On the other hand, newer ones consume roughly $400 \mathrm{~kg}$ per ton of processed cane. In this work was assumed that plants use mechanical grinding, minimizing steam consumption.

In Figures $1 \mathrm{a}$ and $1 \mathrm{~b}$ below are presented the schematics for the gasification system operating during season (6 months) and off-season (1 month), respectively. The total amount of bagasse used during season and off-season was defined so that electricity power produced in each scenario was the same (58 $\left.\mathrm{MW}_{\mathrm{E}}\right)$.

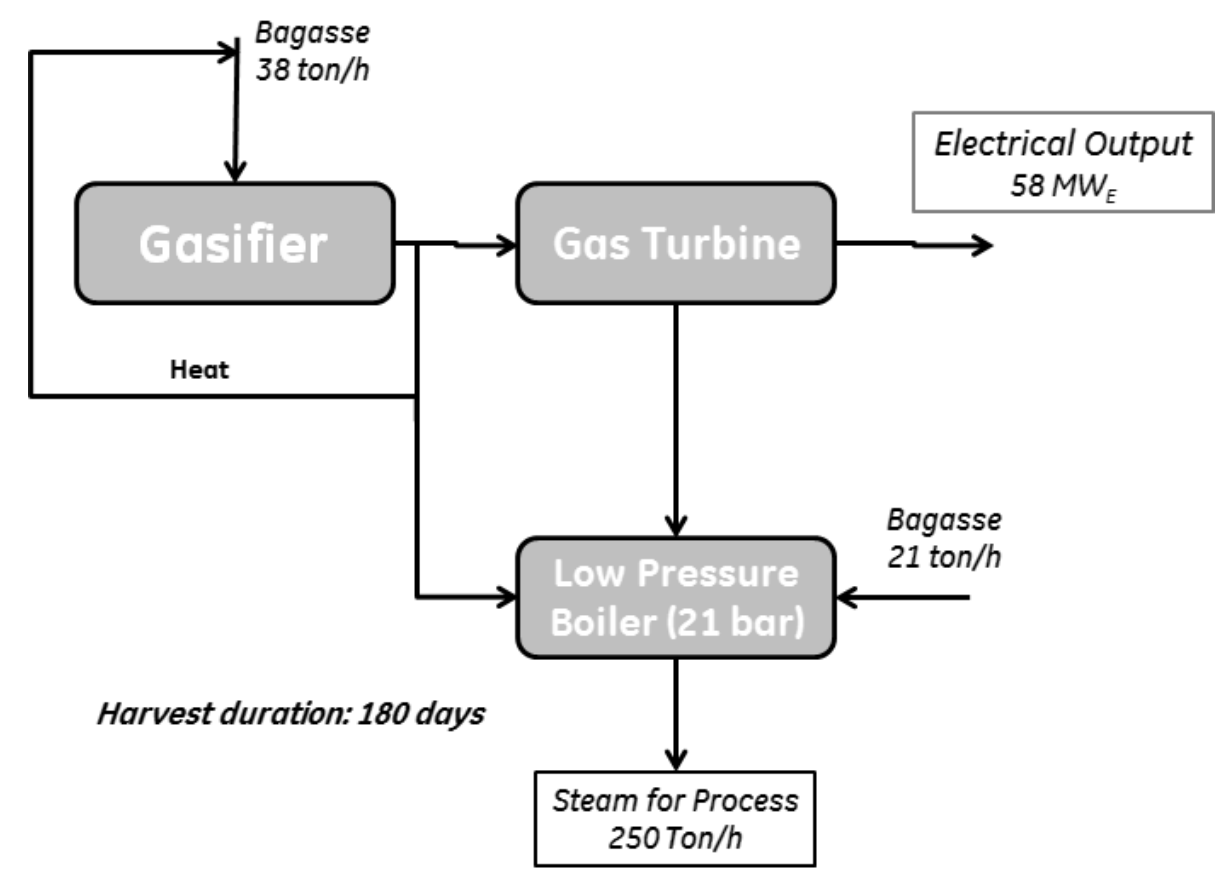

Figure 1a: Gasification operation during Season (6 months) 
ISSN: $1415-7314$

ISSN online: $2317-6717$

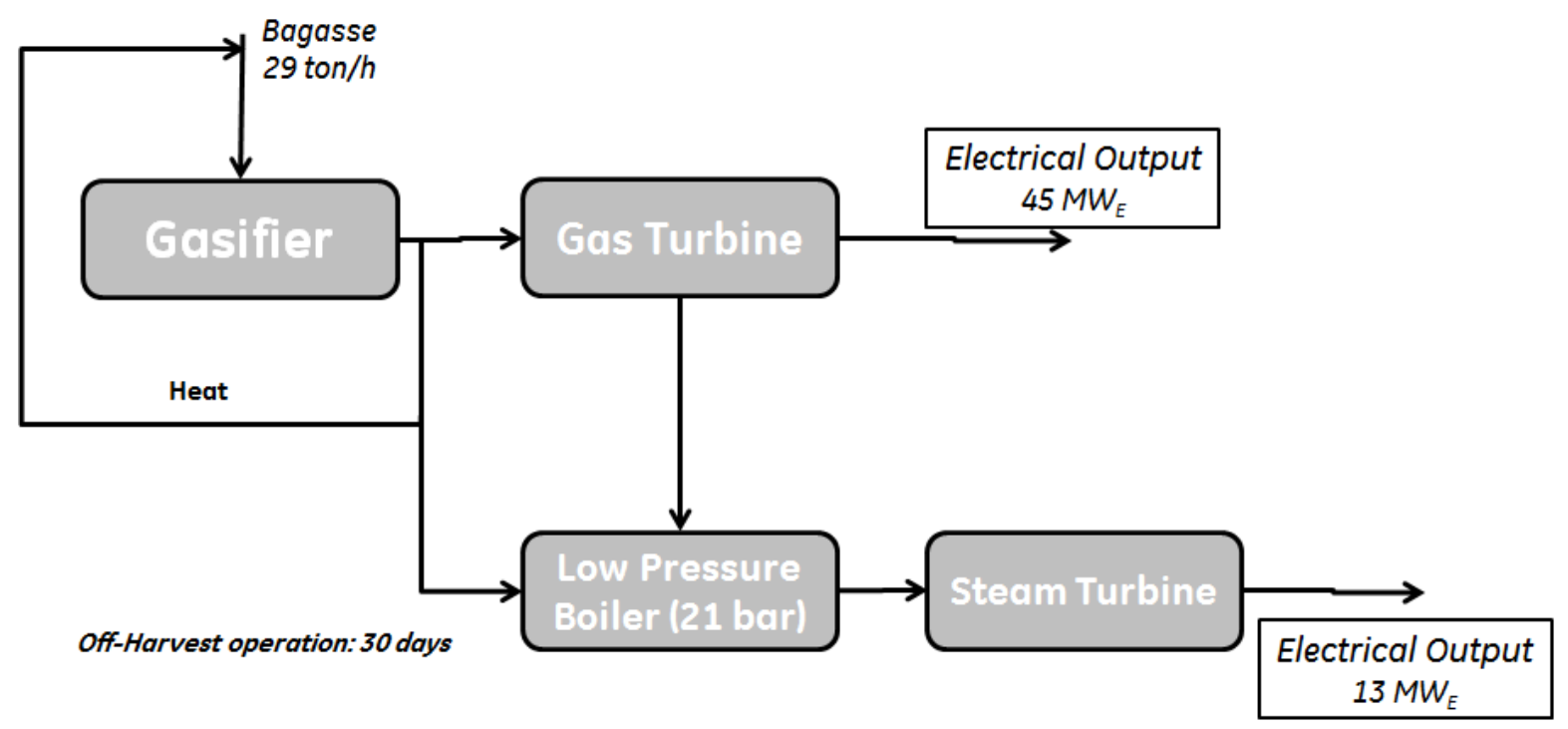

Figure 1b: Gasification operation during Off-Season (1 month)

In the same manner, in Tables $1-5$ are shown the details about the main assumptions and how the numbers in Figures 1a and $1 \mathrm{~b}$ and Tables 6 and 7 were generated.

Table 1: General assumptions

\begin{tabular}{|c|c|c|}
\hline \multicolumn{2}{|c|}{ Mill's Operation } \\
\hline Crushed cane per year & $\mathrm{t}_{\text {Cane }}$ & 2000000 \\
\hline Bagasse/cane Ratio & $\mathrm{kg}_{\text {Bag }} / \mathrm{kg}_{\text {Cane }}$ & 0.14 \\
\hline Bagasse produced per year & $\mathrm{t}_{\text {Bag }}$ & 280000 \\
\hline$\%$ bagasse gasified in the season & - & 0.59 \\
\hline$\%$ bagasse gasified out of season & - & 0.07 \\
\hline$\%$ of burned bagasse & & 0.34 \\
\hline Season duration & days & 183 \\
\hline Days out of season & days & 30 \\
\hline
\end{tabular}


Table 2: General assumptions to gasifier

\begin{tabular}{|c|c|c|}
\hline \multicolumn{2}{|c|}{ Gasifier } & \\
\hline Gas/bagasse Ratio & $\mathrm{kg}_{\text {Gas }} / \mathrm{kg}_{\text {Bag }}$ & 2.8 \\
\hline LHV Gas & $\mathrm{MJ} / \mathrm{kg}_{\text {Gas }}$ & 5 \\
\hline Gas temperature leaving gasifier & Celsius & 550 \\
\hline Gas temperature after cooling & Celsius & 150 \\
\hline Specific Heat of Gas & $\mathrm{kJ} / \mathrm{kgK}$ & 2.3 \\
\hline Fraction of heat recirculated to gasifier & $\%$ & 35 \\
\hline
\end{tabular}

Table 3: General assumptions to Gas Turbine

\begin{tabular}{|c|c|c|}
\hline \multicolumn{3}{|c|}{ Gas Turbine } \\
\hline Efficiency & - & 0.4 \\
\hline
\end{tabular}

Table 4: General assumptions to Steam Turbines

\begin{tabular}{|c|c|}
\hline \multicolumn{2}{|c|}{ Look up table - Condensing Turbine } \\
\hline Pressure/Temp & $\mathrm{T}_{\text {Steam }} / \mathrm{MW}_{\mathrm{E}} \mathrm{h}$ \\
\hline 21 bar $/ 300$ Celsius & 6.2 \\
\hline $42 / 420$ & 4.15 \\
\hline $65 / 485$ & 3.75 \\
\hline $81 / 510$ & 3.45 \\
\hline $100 / 530$ & 3.34 \\
\hline $140 / 540$ & 3.25 \\
\hline
\end{tabular}

Table 5: General assumptions to Steam Generator

\begin{tabular}{|c|c|}
\hline \multicolumn{2}{|c|}{ Look up table - Boiler $\mathbf{~} \mathbf{~ J J} / \mathbf{k g}_{\mathrm{H} 2 \mathrm{O}}$} \\
\hline Pressure/Boiler Temp & $\mathrm{kJ} / \mathrm{kg}_{\mathrm{H} 2 \mathrm{O}}$ \\
\hline 21 bar $/ 300$ Celsius & 2854 \\
\hline $42 / 420$ & 3091 \\
\hline $65 / 485$ & 3213 \\
\hline $81 / 510$ & 3255 \\
\hline $100 / 530$ & 3284 \\
\hline $140 / 540$ & 3267 \\
\hline Efficiency & 0.85 \\
\hline LHV bagasse $\left(\mathrm{MJ} / \mathrm{kg}_{\text {Bag }}\right.$ ) & 17 \\
\hline
\end{tabular}


Table 6: General assumptions to Season Operation

\begin{tabular}{|c|c|c|}
\hline \multicolumn{2}{|c|}{ Season Performance } \\
\hline Gasified bagasse & $\mathrm{t}_{\mathrm{Bag}} / \mathrm{h}$ & 37.6 \\
\hline Flow of produced gas & $\mathrm{t}_{\mathrm{Gas}} / \mathrm{h}$ & 105.3 \\
\hline Burned Bagasse & $\mathrm{t}_{\mathrm{Bag}} / \mathrm{h}$ & 21.4 \\
\hline Bagasse used in the season & $\mathrm{t}_{\mathrm{Bag}}$ & 259336 \\
\hline Heat leaving turbine & $\mathrm{MW}_{\mathrm{T}}$ & 87.8 \\
\hline Heat cooling of gas & $\mathrm{MW}_{\mathrm{T}}$ & 17.49 \\
\hline Heat from burned bagasse & $\mathrm{MW}_{\mathrm{T}}$ & 101.2 \\
\hline Steam production & $\mathrm{t}_{\text {Steam/h }}$ & 221.4 \\
\hline $\begin{array}{c}\text { Steam process 1.5bar } \\
\text { with water injection }\end{array}$ & $\mathrm{t}_{\text {Steam/h }}$ & 249.7 \\
\hline $\begin{array}{c}\text { Steam process 1.5bar } \\
\text { with water injection }\end{array}$ & $\mathrm{kg}_{\text {Steam/ }} \mathrm{t}_{\mathrm{Cane}}$ & 548.4 \\
\hline Power production & $\mathrm{MW}$ & 58.5 \\
\hline
\end{tabular}

Table 7: General assumptions to Off-Season Operation

\begin{tabular}{|c|c|c|}
\hline \multicolumn{2}{|c|}{ Off-Season Performance } \\
\hline Gasified bagasse & $\mathrm{t}_{\mathrm{Bag}} / \mathrm{h}$ & 28.7 \\
\hline Flow of produced gas & $\mathrm{t}_{\mathrm{Gas}} / \mathrm{h}$ & 80.4 \\
\hline Heat leaving turbine & $\mathrm{MW}_{\mathrm{T}}$ & 67.0 \\
\hline Heat cooling of gas & $\mathrm{MW}_{\mathrm{T}}$ & 13.3 \\
\hline Steam production & $\mathrm{t}_{\text {Steam/h }}$ & 86.1 \\
\hline Power Production Gas Turbine & $\mathrm{MW}$ & 44.6 \\
\hline Power Production Steam Turbine & $\mathrm{MW}$ & 13.9 \\
\hline Stored Bagasse & $\mathrm{t}_{\mathrm{Bag}}$ & 20664 \\
\hline Total Power Production & $\mathrm{MW}$ & 58.5 \\
\hline
\end{tabular}


The process configuration for the high pressure steam boiler (100 bar) is represented in Figure 2 below.

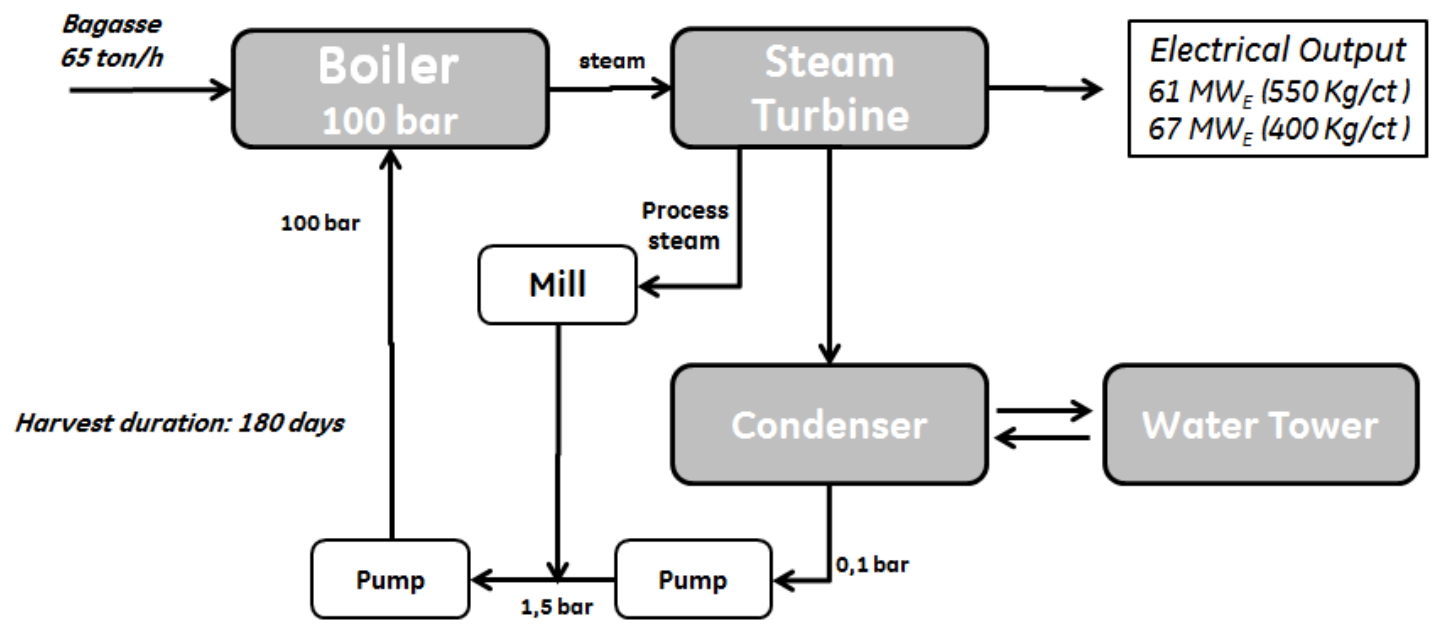

Figure 2 - High Pressure Steam Boiler (100 bar) Diagram Operating During Season Operation (6 months). The other scenarios assessed in this work are shown in Table 8 below.

For the economic evaluation, the following assumptions were adopted:

1. Power Sales

- $\quad$ Equipment's internal consumption: $8 \%$

- $\quad$ Availability: 98\%

- $\quad$ Power Losses: 2\%

- $\quad$ Power Price: $150 \mathrm{R} \$ \mathrm{MWh}$

2. Operational Costs:

- $\quad$ Limestone: 1 ton per MWh (only gasifier)

- $\quad$ Bagasse: zero

- $\quad$ Labor: $480 \mathrm{kR} \$ / \mathrm{Yr}$

- $\quad$ Chemicals: 0,03 R $\$$ /ton of steam

- Maintenance: $5 \%$ of Investment

- $\quad$ Overhead: $3 \%$ of net sales

\section{Results and Discussions}

For cogeneration systems of steam and electricity based on combined cycle and gasification (IGCC), when 21 bar boilers are used, the result is more cost effective, since it is taking advantage of the installed capacity and, for this reason, this scenario is more attractive than the others. Fore other boilers (42 and 65 bar), the increasing in electric power generation is smaller for the investment to be made. Another thing important to note is that the possibility of spreading the bagasse use for yearlong power generation (longer than the harvest season) results in lower CAPEX as smaller gasifiers can be used to process the same quantity of bagasse in a longer period.

Table 8 represents the power generation that can be produced using boiler and using either the high pressure boiler or the fluidized bed gasifier, considering that all cases process the same amount of bagasse (280.000 tons per harvest). Two indexes were created: Generation 
ISSN: $1415-7314$

ISSN online: 2317-6717

Capex and Capacity Capex. The Capacity Capex index is the relation between the total investment and the generation capacity. The Generation Capex index includes another variable to analyze the investment in each situation: the number of operating months per year; it represents the relation between the total investment with the amount of energy generated throughout the year, which varies according to the number of operating months. Consequently, the analysis of these 2 indexes shows that to use the available biomass in eleven months represents the best option, once the capital versus generation allocation will have its lower value.

Table 8: Investment Options

\begin{tabular}{|c|c|c|c|c|c|}
\hline Equipment & $\begin{array}{c}\text { Power Generation } \\
\text { Duration (months) }\end{array}$ & $\begin{array}{c}\text { Power Generation } \\
(\mathrm{MW}) * *\end{array}$ & Investment (MR\$) & $\begin{array}{c}\text { Generation CAPEX } \\
(\mathrm{R} \$ \text { /MWh) }\end{array}$ & $\begin{array}{c}\text { Capacity CAPEX } \\
\text { (MR\$/MW) }\end{array}$ \\
\hline \multirow{2}{*}{100 bar Boiler } & 6 & 67 & 182 & 622 & 2.7 \\
\hline \multirow{2}{*}{ Gasifier } & 6 & 116 & 352 & 693 & 3.0 \\
\cline { 2 - 6 } & 7 & 93 & 301 & 634 & 3.2 \\
\cline { 2 - 6 } & 9 & 63 & 228 & 556 & 3.7 \\
\hline & 11 & 48 & 189 & 493 & 4.0 \\
\hline
\end{tabular}

* Harvest Duration: 6 months

** Process Steam Consumption: $400 \mathrm{Kg}$ of steam per cane ton and Boiler with $21 \mathrm{Kg} / \mathrm{cm}^{2}$ for gasifier options

**** Without losses and availability impacts

Table 9 compares for each case the real CAPEX against its target value where in a discounted cash flow model, its internal rate of return (IRR) would reach $10 \%$.

Table 9: Economic Evaluation comparing 100 bar Boiler with gasification

\begin{tabular}{|c|c|c|c|}
\hline Equipment & $\begin{array}{l}\text { Power Generation } \\
\qquad(\mathrm{MW})^{*}\end{array}$ & CAPEX (MR\$) ${ }^{*}$ & $\begin{array}{c}\text { Max Inv (MR\$) for } \\
\text { IRR }=10 \%^{* *}\end{array}$ \\
\hline 100 bar Boiler & 67 & 182 & 167 \\
\hline \multirow{4}{*}{ Gasifier } & 116 & 352 & 331 \\
\hline & 93 & 301 & 304 \\
\hline & 63 & 228 & 256 \\
\hline & 48 & 189 & 235 \\
\hline
\end{tabular}

* Above $30 \mathrm{MW}$, scale-up factor of 0,7 used

*** Power Price $=150 \mathrm{R} \$ \mathbf{M W h}$ net taxes 
Only the cases where the real CAPEX are lower than Max Inv (MR\$) for IRR $=10 \%$, the target CAPEX show some economic attractiveness. After this assumption, only the gasifier having offseason operation shows economic attractiveness.

\section{Conclusions}

1. The result of the economic evaluation, under the established considerations shows that, with the current market prices and gasification costs, the option to sell electricity from sugarcane mills to the free market is feasible.

2. In order to promote renewable energy technologies like biomass gasification, it is necessary to develop and stablish temporary measures to guarantee a preferential price for energy being produced by gasification. In other words, it will be necessary to implement and regulate closed markets, exclusive for renewable energy producers, including those using gasification. However, at this time, it has not announced any concrete measures in this regard, and there is no information on the existence of an initiative to be implemented shortly.

3. Under the considerations made in this report, for new sugar cane plants gasification could be economically more interesting to produce power and energy from sugar cane bagasse.

4. As at the moment most biofuels are not competitive on a free market, their economic advantage depends highly on political support and reliable long-term stable political framework conditions with an enough timeframe for the development, construction and operation of biomass gasification plants.

5. Use available biomass during eleven months represents a better option than only during the season (6-7 months), once the capital versus generation allocation will have its lower value at this period.

\section{References}

BOERRIGTER, H. \& RAUCH, R. 2006. Review of applications of gases from biomass gasification. ECN, Biomass, Coal \& Environmental Research.

CENBIO 2002. Comparação entre tecnologias de gaseificação de biomassa existentes no brasil e no exterior e formação de recursos humanos na região norte. Relatório corrigido do Convenio FINEP / CETENERG 23.01.0695.00. São Paulo: Centro Nacional de Referencia em Biomassa.

CIFERNO, J. P. \& MARANO, J. J. 2002. Benchmarking biomass gasification technologies for fuels, chemicals and hydrogen production. Washington D.C.: US Department of Energy, National Energy Technology Laboratory.

REN21 2011. REN 21 Renewables 2011 Global Status Report. Paris: Renewable Energy Policy Network for the 21 St Century. 